\title{
TEPAS KEPRAJURITAN SEBAGAI SUATU WADAH ORGANISASI BAGI PRAJURIT KERATON YOGYAKARTA
}

Anna Galuh Indreswari

\begin{abstract}
ABSTRAK
Penelitian ini mempunyai tujuan untuk mencari tahu mengenai hal-hal penting yang berkaitan dengan Tepas Keprajuritan di Keraton Yogyakarta. Hal-hal penting mengenai Tepas Keprajuritan sebagai suatu organisasi yang didirikan untuk kemajuan prajurit Keraton Yogyakarta khususnya secara manajemennya. Hal-hal penting tersebut, di antaranya yaitu: (1) struktur organisasinya; (2) manajemennya; (3) sistem perekrutan pegawai; (4) penempatan dan rotasi; dan (5) budaya kekuasaan di dalam organisasi tepas.

Penelitian yang mengambil Tepas Keprajuritan sebagai obyeknya ini sudah barang tentu membutuhkan metode penelitian. Metode penelitian berguna untuk menemukan jawaban atas segala pertanyaan atau permasalahan. Penggunaan metode penelitian dalam memecahkan permasalahan atau mencari jawab atas pertanyaan penelitian menggunakan beberapa metode dari disiplin ilmu yang berbeda. Penelitian ini menggunakan metode multidisiplin. Beberapa metode dari disiplin ilmu yang berbeda di antaranya, yaitu: ekonomi; estetika; sejarah; dan antropologi. Sedangkan metode pencarian data dilakukan dengan cara, yaitu: observasi; wawancara; dokumentasi; dan pustaka.

Penelitian ini menghasilkan kesimpulan bahwa Tepas Keprajuritan adalah suatu organisasi yang strukturnya dibagi dua, yaitu: secara admininstratif dan seremonial. Tepas adalah suatu organisasi yang mengutamakan pendekatan secara kekeluargaan. Tepas Keprajuritan didirikan dengan tujuan utamanya adalah untuk meningkatkan kesejahteraan para anggota prajurit Keraton Yogyakarta. Selain itu, adanya Tepas Keprajuritan, dapat menjaga rasa kebersamaan dan kerukunan di antara anggota prajurit Keraton Yogyakarta serta para pengurus tepas dalam suatu wadah organisasi.
\end{abstract}

Keywords: Tepas Keprajuritan, Keraton Yogyakarta, organisasi, manajemen.

\section{PENDAHULUAN}

Tepas Keprajuritan adalah suatu organisasi di dalam Keraton Yogyakarta yang mengurusi hal-hal yang berkaitan dengan keperluan prajurit. Tepas Keprajuritan didirikan pada tanggal 2 Maret 1971, dengan persetujuan Sri Sultan Hamengku Buwana IX (Sultan HB IX)
(Yuwono Sri Suwito, 2009: 13). Pemrakarsa berdirinya adalah Bandoro Raden Mas Herjuno Darpito, sekarang Sri Sultan Hamengku Buwono $X$ (Sultan HB X), bersama beberapa kerabat dalem. Kerabat dalem yang turut mendukung berdirinya tepas adalah Raden Mas (R.M) Tirun Marwito, Karebet Sutardi, Raden Mas (R.M)

*) Anna Galuh Indreswari, (galuhindres@gmail.com), Staf Pengajar Program studi Kriya Seni, Jurusan Kriya, Fakultas Seni Rupa, Institut Seni Indonesia Yogyakarta. 
Mudjanat Tistama, Kanjeng Raden Tumenggung (KRT) Brajanegara dan Raden Bekel (R.B) Niti Gurnito (Yuwono Sri Suwito, 2009: 13).

Menurut wawancara dengan Kantor Tepas Keprajuritan sendiri masih terletak dalam wilayah tanah keraton. Tepas Keprajuritan menempati tanah keraton seluas kurang lebih 15 meter X 20 meter, berdekatan dengan kantor Tepas Darah Dalem. Letak kantornya di kompleks Pracimosono Keraton Yogyakarta (Kusumanegara, dalam wawancara pada hari Kamis, 13 Mei 2010 di Tepas Keprajuritan Keraton Yogyakarta).

\section{Pengorganisasian}

a. Struktur Organisasi

Tepas keprajuritan adalah suatu organisasi yang secara struktural dibagi menjadi dua, yaitu secara administratif dan seremonial. Tepas Keprajuritan didirikan di bawah pengawasan Penghageng dan Manggalayuda (Kusumanegara, dalam wawancara pada hari Kamis, 13 Mei 2010 di Tepas Keprajuritan Keraton Yogyakarta). Penghageng adalah kepala administrasi dalam tepas keprajuritan, yang saat ini dijabat oleh Kanjeng Gusti Pangeran Haryo (KGPH) Hadiwinata. Penghageng membawahi Carik, Kahartaken dan Lumaksana. Carik dapat diartikan dengan sekertaris, dan Kahartaken berarti bendahara. Lumaksana adalah bagian umum, dalam hal ini kurir. Carik saat ini dipegang oleh Nyi Mas Yudo Hastuti, Kahartaken oleh Nyi Mas Bekel Yudo Lestari dan Lumaksana oleh Mas Bekel Prajoko (Kusumanegara, dalam wawancara pada hari Kamis, 13 Mei 2010 di Tepas Keprajuritan Keraton Yogyakarta).

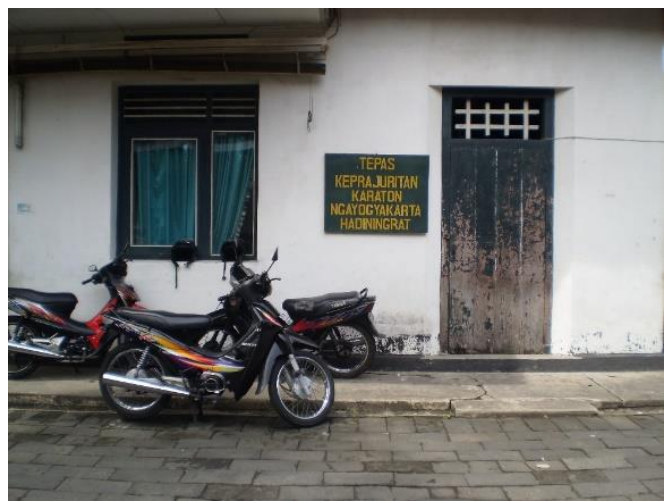

Gbr.I. Kantor Tepas Keprajuritan

Keraton Yogyakarta (Tampak depan).

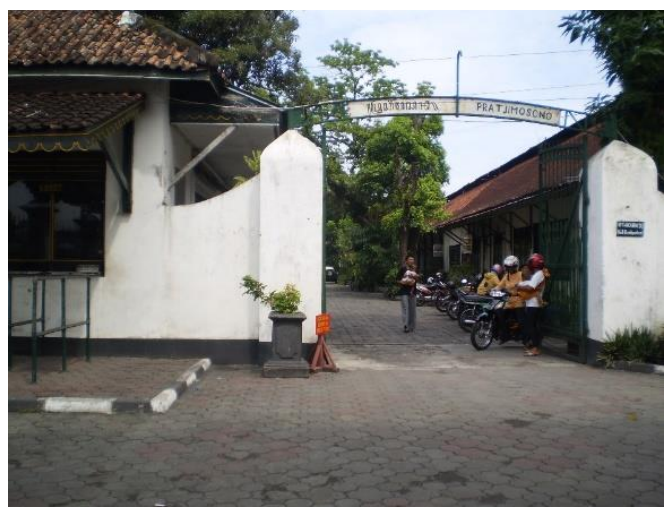

Gambar 3. Gerbang Pintu Masuk Tepas Keprajuritan Keraton Yogyakarta (Tampak depan).

Saat ini, jabatan Manggalayuda dipimpin oleh Gusti Bandara Pangeran Haryo (GBPH) Yudaningrat. GPBH Yudaningrat adalah adik Sultan HB $X$. Sebagai Manggalayuda, GPBH Yudaningrat adalah panglima besar prajurit dalam upacara garebeg yang diselenggarakan oleh keraton. Seorang Manggalayuda membawahi Pandhéga, Kaptèn, Panji, Sérsan dan Jajar. Pandhéga dapat diartikan dengan Kaptèn Parèntah, dalam bertugas dibantu oleh Kaptèn. Kapten membawahi Panji atau Lurah, Sérsan, dan Jajar atau prajurit (Yuwono Sri Suwito, 2009:15). 


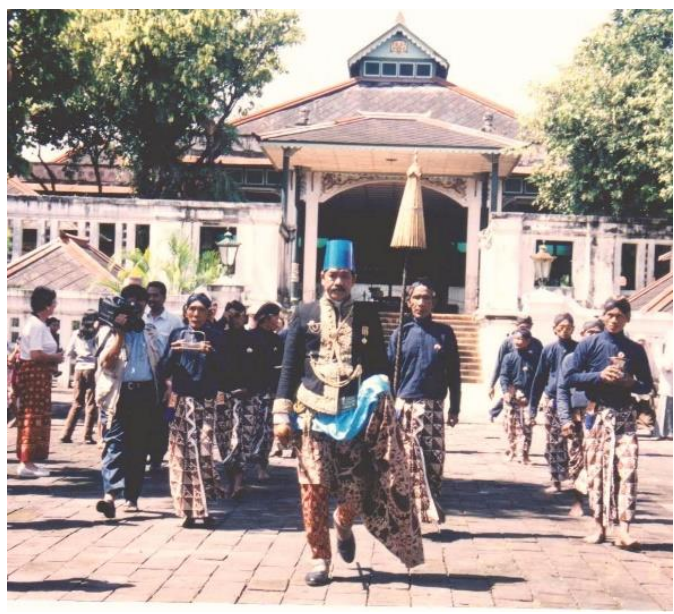

Gambar 4. Gusti Bandara Pangeran Haryo (GBPH) Yudaningrat sebagai Manggalayuda Prajurit Keraton Yogyakarta.

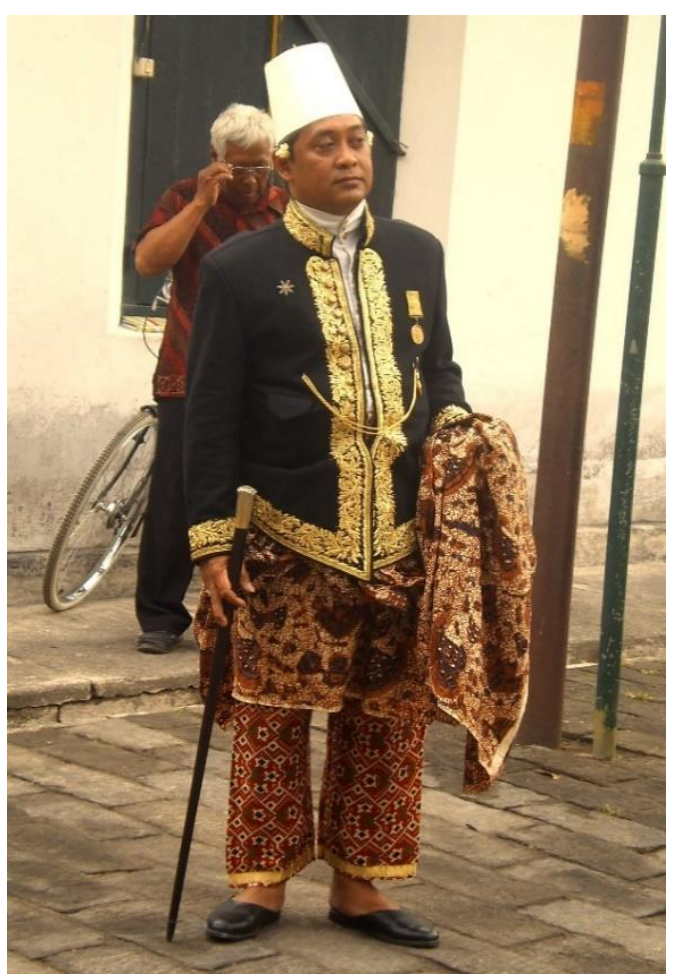

Gambar 5. Raden Mas (RM) Pramutama sebagai Kapten Bregada Prajurit Keraton Yogyakarta.

\section{b. Pendekatan Klasik/ Tradisional/ Keluarga}

Tepas Keprajuritan adalah sebuah organisasi yang memakai sistem pendekatan kekeluargaan. Hal-hal yang berhubungan dengan organisasi diselesaikan dan dilakukan dengan cara kekeluargaan (Kusumanegara, dalam wawancara pada hari Kamis, 13 Mei 2010 di Tepas Keprajuritan Keraton Yogyakarta). Hal-hal bersifat kekelurgaan yang cukup jelas terlihat adalah misalnya yang menyangkut sistem perekrutan pegawai. Pendekatan keluarga ini sesuai dengan etiket seorang priyayi seperti yang dituliskan oleh Clifford Geertz. Clifford Geertz menuliskan dalam bukunya bahwa ada empat prinsip pokok yang menjiwai etiket priyayi. Keempat prinsip pokok tersebut, yaitu: (1) bentuk yang sesuai untuk pangkat yang tepat; (2) ketidaklangsungan; (3) menghindari tiap perbuatan yang menunjukkan kengawuran; dan (4) penguasaan diri (Clifford Geertz, 1983: 326).

\section{c. Penempatan dan Rotasi}

Tepas adalah bagian dari Keraton Yogyakarta, tetapi para anggota prajurit tidak terikat dengan kedudukan atau pangkat tertentu di dalam keraton (Yuwono Sri Suwito, 2009: 14). Hal ini disebabkan karena pada masa pemerintahan Sri Sultan Hamengku Buwana IX (HB IX), urusan prajurit masuk dalam Kawedanan Hageng Punakawan yang statusnya sebagai abdi dalem penuh. Masa sekarang, prajurit keraton berada di bawah Tepas Keprajuritan (Kusumanegara, dalam wawancara pada hari Kamis, 13 Mei 2010 di Tepas Keprajuritan Keraton Yogyakarta).

Sesuai dengan etiket priyayi, yaitu penempatan pegawai untuk bregada prajurit disesuaikan dengan pangkat dan posisi yang tepat (Clifford Geertz, 1983: 326). Penempatan dengan pangkat dan posisi yang tepat untuk bregada adalah 
menggantikan posisi lama yang ditinggalkan oleh prajurit lama. Posisi sebagai Penghageng, Manggalayuda dan Pandhega biasanya dipimpin oleh darah dalem. Darah dalem adalah seseorang yang mempunyai gelar ningrat dari semenjak lahir (Kusumanegara, dalam wawancara pada hari Kamis, 13 Mei 2010 di Tepas Keprajuritan Keraton Yogyakarta).

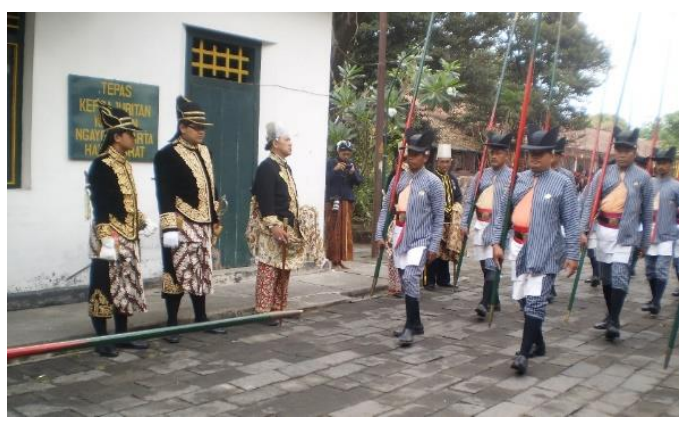

Gambar 6. Prajurit Keraton Yogyakarta mengawali tugas dalam upacara Garebeg dari kantor Tepas Kaprajuritan.

\section{d. Budaya Kekuasaan}

Kepemimpinan tepas kaprajuritan berada di tangan dua putra dalem, yaitu GBPH Hadiningrat dan GBPH Yudaningrat. Mereka mewakili sikap hidup orang Jawa yang taat terhadap adat istiadat nenek moyangnya, mengutamakan kepentingan umum atau masyarakatnya dari pada kepentingan pribadinya. Pola kepemimpinannya tergambar jelas dalam pedoman hidupnya yaitu: aja dumeh dan aja mumpung (Budiono Herusatoto, 2008: 130).

Falsafah jawa mengatakan bahwa tujuan pemimpin adalah rame ing gawe, sepi ing pamrih, sugih tanpa banda, lan menang tanpa ngasoraké. Falsafah ini berarti giat bekerja, menjauhi keserakahan, kaya akan kebijaksanaan dan saling tolong menolong, dan berhasil mencapai tujuan tanpa merendahkan harga diri lawannya (Budiono Herusatoto, 2008: 130).

e. Manajemen

Manajemen tepas berkaitan dengan stafing, pengelolaan sumber dana dan pengaturan kepangkatan prajurit.

a. Stafing

Kepegawaian dalam tepas keprajuritan dibagi menjadi dua yaitu: administratif dan seremonial. Pegawai administratif dan anggota bregada prajurit diambil dengan memerhatikan kebutuhan pegawai dalam struktur organisasi. Pengambilan pegawai di dalam tepas masih menggunakan sistem kekeluargaan. Penggunaan sistem ini didasarkan atas hubungan kekerabatan dan relasi. Masyarakat umum yang ingin menjadi bregada prajurit dapat pula masuk melalui proses pendaftaran dan magang. Proses magang ini relatif lama kurang lebih lima tahun, ada pula yang sudah magang 10 tahun tetapi belum diangkat menjadi prajurit keraton. Proses ini dianggap tidak efektif untuk menjadi prajurit keraton.

Proses pengambilan pegawai yang lebih efektif adalah adanya hubungan kekerabatan antara prajurit dan calon prajurit. Biasanya, calon prajurit tersebut direkomendasikan oleh anggota prajurit yang sudah senior. Cara lainnya adalah calon prajurit menggantikan prajurit yang sudah sepuh (tua) atau sudah meninggal. Proses pengambilan pegawai di bagian administrasi juga sama seperti proses dalam bregada prajurit. Sistemnya masih menggunakan sistem kekeluargaan. Sistem tersebut mempertimbangkan adanya hubungan kekerabatan dalam organisasi Tepas Keprajuritan (Kusumanegara, dalam 
wawancara pada hari Kamis, 13 Mei 2010 di Tepas Keprajuritan Keraton Yogyakarta). b. Pengelolaan Sumber Dana

Dana prajurit didapatkan dari dua sumber keuangan yaitu pengadaan loket pariwisata Keraton Yogyakarta dan bantuan dana dari Keraton Yogyakarta setiap bulannya. Loket pariwisata adalah tiket masuk menuju beberapa tempat di wilayah keraton yang telah dijadikan obyek wisata. Loket pariwisata Keraton Yogyakarta letaknya menyatu dengan kantor Tepas Keprajuritan didirikan untuk mendukung kegiatan para prajurit keraton. Kegiatan para prajurit meliputi penyelenggaraan upacara garebeg, pembayaran honor, dan pengadaan kostum prajurit (Kusumanegara, dalam wawancara pada hari Kamis, 13 Mei 2010 di Tepas Keprajuritan Keraton Yogyakarta). Loket Pariwisata dibentuk bersamaan dengan berdirinya Tepas Keprajuritan. Loket dibuka pada pukul 08.00-14.00 WIB. Loket ditutup pada harihari tertentu berkaitan dengan acara keraton, misalnya Hadeging Keraton Ngayogyakarta Hadiningrat. Loket tetap dibuka pada hari libur kalender, selain Idul Fitri (Nyi Mas Yudo Hastuti, dalam wawancara pada hari Senin, 17 Mei 2010 di Tepas Keprajuritan Keraton Yogyakarta).

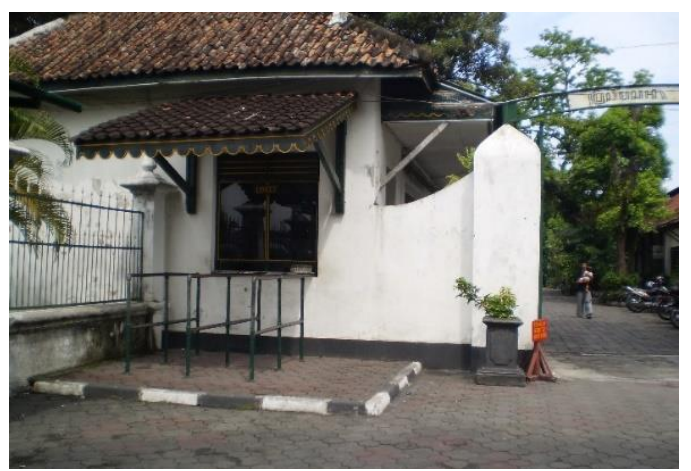

Gambar 7. Loket Pariwisata Tepas Keprajuritan Keraton Yogyakarta (Tampak depan).
Harga tiket untuk hari biasa adalah Rp. 3000,- per orang, sedangkan untuk hari libur kalender dipatok seharga Rp. 10.000,per orang. Pengambilan foto dan video di lingkungan keraton juga dipungut biaya sebesar Rp. 1000 per kamera, dan Rp. 2000,- per video. Wisatawan asing dikenakan harga tersendiri yaitu Rp. 5000,per orang untuk hari biasa, sedangkan hari libur kalender Rp. 20.000,- per orang. Rombongan wisatawan lokal dipatok Rp. 7000,- per orang dan rombongan wisatawan asing Rp. 15.000,- per orang (Nyi Mas Yudo Hastuti, dalam wawancara pada hari Senin, 17 Mei 2010 di Tepas Keprajuritan Keraton Yogyakarta).

Pembentukan loket sebagai sarana untuk menghimpun dana bagi prajurit keraton mempunyai riwayat tersendiri. Dahulu, prajurit keraton secara kontroversial pernah dibubarkan oleh Sri Sultan Hamengku Buwana (Sultan HB IX). Prajurit keraton dibubarkan, karena Sultan HB IX melalui radio asing mendengar bahwa Jepang sudah masuk ke Yogyakarta. Sultan HB IX khawatir apabila Jepang masuk ke Yogyakarta akan mempergunakan prajurit keraton untuk kepentingan Jepang (Kusumanegara, dalam wawancara pada hari Kamis, 13 Mei 2010 di Tepas Keprajuritan Keraton Yogyakarta).

Kekawatiran tersebut ternyata beralasan, sewaktu jepang tiba di Yogyakarta, mereka menanyakan keberadaan bregada prajurit keraton untuk memperkuat pertahanan jepang. Pihak jepang merasa kecewa karena HB IX sudah tidak mempunyai bregada prajurit. Mereka melucuti senjata para bregada yang disimpan di gudang keraton. Pembubaran 
prajurit keraton oleh Sultan HB IX tersebut ternyata hanyalah stategi beliau untuk mengelabuhi Jepang. Para prajurit tidak benar-benar dibubarkan tetapi ditempatkan sebagai abdi dalem Keraton Yogyakarta. Pembubaran semu ini berlanjut sampai dengan tahun 1970an (Kusumanegara, dalam wawancara pada hari Kamis, 13 Mei 2010 di Tepas Keprajuritan Keraton Yogyakarta).

Sultan HB X yang pada waktu itu masih bergelar Bandara Raden Mas Herjuno Darpito memrakarsai menghidupkan kembali prajurit keraton. Beliau bersama dengan kerabat keraton yang lain membentuk berdirinya prajurit keraton. Prajurit keraton awal dibentuknya berjumlah empat bregada (Kusumanegara, dalam wawancara pada hari Kamis, 13 Mei 2010 di Tepas Keprajuritan Keraton Yogyakarta). Pembentukan kembali prajurit keraton ini, tentunya memerlukan dana untuk kegiatan keprajuritan. Dana tersebut akhirnya diperoleh dari berdirinya loket di kantor tepas keprajuritan dan bantuan dari keraton Yogyakarta.

Gaji pengurus Tepas Keprajuritan di bawah pimpinan KGPH Hadiningrat diberikan berdasarkan pendapatan dari loket (Hastuti, 2010). Survey yang dilakukan di lapangan belum mendapatkan angka pasti mengenai kisaran gaji masing-masing pengurus administrasi. Pembagian berdasarkan pendapatan loket pun belum ditemukan teknik pembagiannya, karena informasinya masih relatif sulit untuk diberikan.

Honor anggota bregada prajurit di bawah kepemimpinan Gusti Bandara Pangeran Haryo Yudaningrat, sebagai Manggalayuda, diberikan pada saat penyelenggaraan peristiwa tertentu. Peristiwa tersebut adalah seperti upacara garebeg. Para bregada tingkat Jajar menerima honor sebesar Rp. 2.750,- per prajurit untuk setiap garebeg, sedangkan para pembesar prajurit seperti Manggalayuda, Pandhéga, dan Panji menerima honor berkisar antara Rp. 3.500,sampai Rp. 4.500,- per orang. Tunjangan atau dapat diartikan bonus diterima oleh anggota bregada prajurit pada saat Idul Fitri. Mereka menerima tunjangan hari raya sebesar Rp. 5.000,- per orang. Para pejabat prajurit menerima kurang lebih sekitar Rp. 7500,- per orang (Kusumanegara, dalam wawancara pada hari Kamis, 13 Mei $2010 \mathrm{di}$ Tepas Keprajuritan Keraton Yogyakarta).

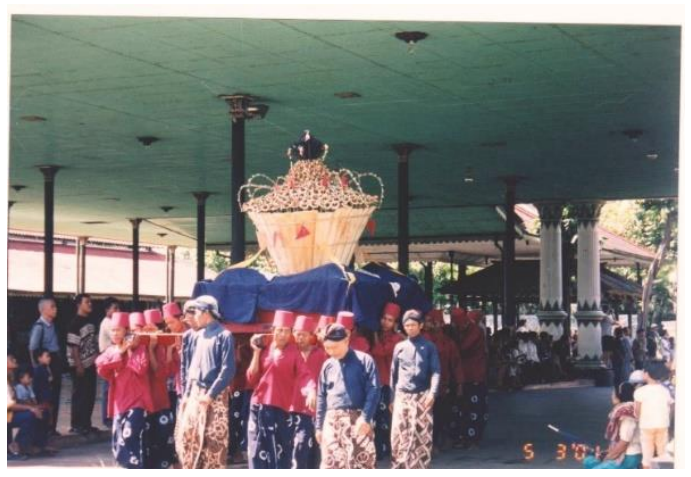

Gambar 8. Gunungan Wadon pada Upacara Garebeg di Keraton Yogyakarta. 


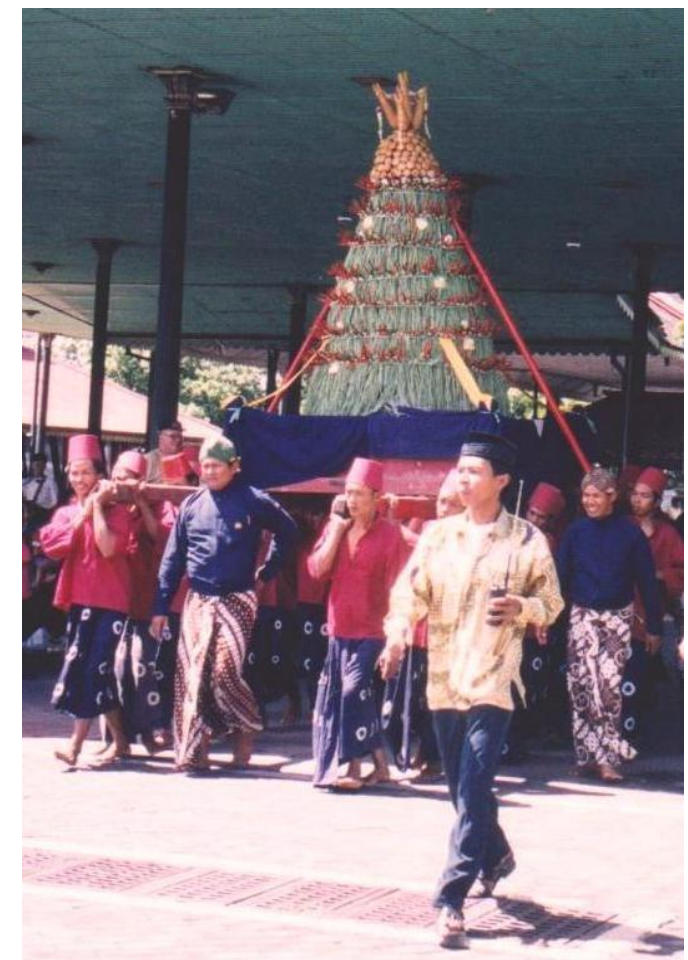

Gambar 8. Gunungan Lanang pada Upacara Garebeg di Keraton Yogyakarta

\section{c. Pengaturan Kepangkatan}

$$
\text { Kepangkatan dalam Tepas }
$$

Keprajuritan dibagi dua yaitu secara administrasi dan seremonial. Secara administrasi, pimpinan tertinggi adalah Penghageng yang kepangkatannya melalui penunjukkan langsung dari Sultan HB X. Penghageng mengangkat pegawai bawahannya melalui penunjukkan langsung terhadap orang-orang yang dianggap mempunyai kualitas di bidangnya. Pegawai tesebut bekerja sesuai dengan bidang pekerjaan dan pangkatnya.

Secara seremonial, pimpinan tertinggi adalah Manggalayuda. Manggalayuda berada dibawah pimpinan Sultan HB X. Manggalayuda memimpin bregada prajurit Keraton Yogyakarta. Pangkat sebagai Penghageng dan Manggalayuda ini biasanya dipegang oleh darah dalem (Kusumanegara, dalam wawancara pada hari Kamis, 13 Mei 2010 di Tepas Keprajuritan Keraton Yogyakarta).

\section{f. Job Description}

Tugas masing-masing jabatan berbeda-beda, sesuai dengan pembagian kerja atau job description. Penghageng mempunyai tugas membuat agenda kegiatan keprajuritan, menghadiri acaraacara keprajuritan dan mempunyai wewenang memberikan teguran kepada bawahannya secara administratif. Carik berurusan dengan pembuatan surat menyurat dan agenda kegiatan prajurit, Kahartaken bertugas sebagai pengelola dana prajurit. Lumaksana mengurusi masalah penyampaian berita kaprajuritan baik secara lisan maupun dengan surat menyurat (Kusumanegara, dalam wawancara pada hari Kamis, 13 Mei 2010 di Tepas Keprajuritan Keraton Yogyakarta).

Tugas dalam organisasi Tepas Keprajuritan saat diadakan upacara seremonial keraton diperintah oleh Manggalayuda. Manggalayuda bertugas mengawasi dan bertanggung jawab atas bregada prajurit. Tugas untuk menyiapkan bregada dilaksanakan oleh Pandhéga. Setiap bregada dipimpin oleh seorang kaptèn, untuk bregada Surakarsa dan Bugis dipimpin oleh Wedana. Tugas Kaptèn adalah mengatur dan memerintah keseluruhan Jajar atau prajurit dalam bregada (Yuwono Sri Suwito, 2009:15).

\section{PENUTUP}

Tepas Keprajuritan adalah suatu organisasi keprajuritan Keraton Yogyakarta. Tepas Keprajuritan didirikan dengan tujuan untuk kesejahteraan dan menjaga rasa kebersamaan para pengurus dan anggota prajurit keraton dalam suatu wadah 
organisasi (Kusumanegara, dalam kepada masyarakat sekitarnya ataupun wawancara pada hari Kamis, 13 Mei 2010 di masyarakat dari luar daerah.

Tepas Keprajuritan Keraton Yogyakarta). Tepas Keprajuritan mempunyai sistem kekeluargaan di dalam menjalankan keorganisasiannya.

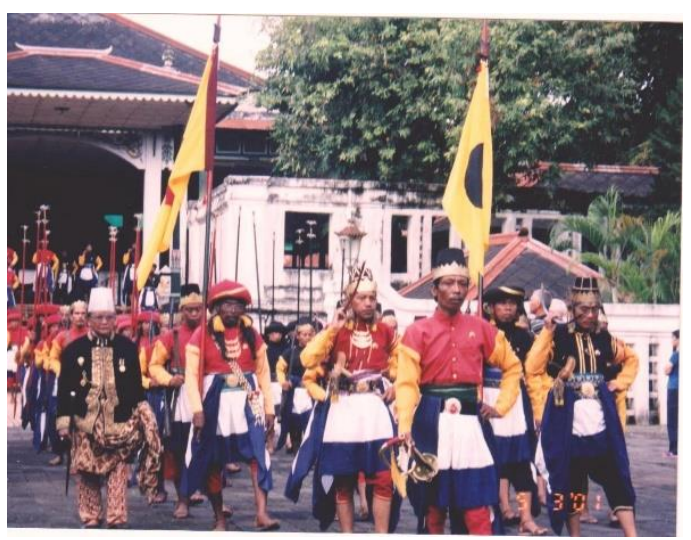

Gambar 10. Prajurit Nyutra sebagai salah satu bregada prajurit Keraton Yogyakarta.

Hal ini cukup terlihat dalam perekrutan pegawai atau prajurit keraton, baik administrasi maupun seremonial. Beberapa permasalahan sering diselesaikan secara intern dalam suasana kekeluargaan, baik yang menyangkut punishment maupun reward. Oleh karena itu, ada beberapa saran yang mungkin bisa dilakukan untuk kemajuan organisasi Tepas Keprajuritan, yaitu:

a. Suatu organisasi memerlukan dokumen tertulis untuk berbagai kegiatan dan aturan yang berlaku. Tepas Keprajuritan memerlukan pembuatan dokumen yang lebih terperinci dalam setiap kegiatannya, karena selama survey ternyata masih minim dokumentasi.

b. Perekrutan pegawai sebaiknya mulai dipikirkan dari masyarakat umum bukan kalangan keraton. Hal ini juga sebagai sarana pembelajaran dan pelestarian budaya adat keraton 